\title{
Infection prevalence and phylogenetic analysis of Perkinsus olseni in Ruditapes philippinarum from East China
}

\author{
Shao-qiang Wu, Cai-xia Wang, Xiang-mei Lin*, Zong-xiang Wang, Xiao-fei Li, \\ Jian Liu, Jun-hua Deng, Song-yin Qiu
}

Institute of Animal and Plant Quarantine, Chinese Academy of Inspection and Quarantine, Beijing 100029, PR China

\begin{abstract}
The prevalence of Perkinsus sp. infection in Manila clam Ruditapes philippinarum was investigated in the coastal areas of east China. Thirteen groups of clams were collected from 5 sites: Dandong and Qingdao Bays (Yellow Sea), Weifang Bay (Bohai Sea), and Ningbo and Fuzhou Bays (East China Sea). The clams were tested for perkinsosis infection using Ray's fluid thioglycollate medium culture assay. Perkinsus sp. was found in samples from all 5 sites from May 2008 to May 2009. Infection prevalence ranged from 43.75 to $95.83 \%$, and was significantly higher in October than in May. The only 3 uninfected groups of clams were collected from Weifang Bay, the site farthest from the ocean. There was no difference in the prevalence of infection among the remaining 4 sites. The conserved internal transcribed spacer regions of the ribosomal RNA gene complex in each of the Perkinsus sp. isolates were amplified by PCR. The resulting amplicons were sequenced and phylogenetically analyzed. All the Perkinsus isolates were identified as Perkinsus olseni.
\end{abstract}

KEY WORDS: Perkinsus olseni · Ruditapes philippinarum · Infection prevalence · Phylogenetic analysis · China

Resale or republication not permitted without written consent of the publisher

\section{INTRODUCTION}

Filter-feeding bivalves such as clams and oysters are an important component of marine ecosystems and play a critical role in maintaining water quality. In addition, they form the basis of several valuable fisheries. For example, the Manila clam Ruditapes philippinarum is commonly found on sandy beaches and tidal flats along the coast of China (Park et al. 2006). The intensive culture of these clams plays an important role in the supply of live seafood to local markets and for export. The total area under culture is 967000 ha with an annual production of $10.08 \mathrm{Mt}$ in 2008 in China, which is up to $75 \%$ of the world total production. In recent years, the annual production of clams has declined due to changes in environment quality and diseases. In particular, parasitic diseases such as those caused by Perkinsus pose a serious threat to the health of the coastal ecosystem and the supply of shellfish worldwide (Fernández-Robledo et al. 2008).

Perkinsus is an intracellular parasite of mollusks (Sheppard \& Phillips 2008). Within the genus Perkinsus, $P$. olseni (synonymised with $P$. atlanticus by Murrell et al. 2002) is distributed over a wide range, including the Pacific Ocean around Japan (Choi \& Park 1997, Hamaguchi et al. 1998), Korea (Choi \& Park 1997), New Zealand, Australia (Lester \& Davis 1981), and regions of the European Atlantic and Mediterranean (Dungan \& Reece 2006). Perkinsus spp. are spread by inadvertent transportation of infected clams on ships, by importation of untested and unquarantined ornamental clams (Sheppard \& Phillips 2008), or by the introduction of exotic clam species for intensive cultivation (Elandaloussi et al. 2009). P. olseni infections have been identified in many types of mollusks throughout the world, including carpet shell clams 
Ruditapes decussatus in Spain (Ordas et al. 2001), undulated surf clams Paphia undulata in Thailand (Leethochavalit et al. 2004), venus clams Protothaca jedoensis in Korea (Park et al. 2006), and cockles Austrovenus stutchburyi in New Zealand (Dungan et al. 2007).

The occurrence of perkinsosis in the Republic of Korea, Japan, and China represents a significant threat to the viability of intensive clam culture. Over the past decade, clam harvests in Korea have declined dramatically as a result of recurrent mass mortalities caused by Perkinsus sp. (Park \& Choi 2001). The majority of Manila clam populations in Japan are highly infected with $P$. olseni, resulting in population declines and some of the lowest population levels since the 1980s (Hamaguchi et al. 1998, Shimokawa et al. 2010). Unidentified Perkinsus species have been isolated from the clam Ruditapes philippinarum along the northeast coast of China in the Yellow Sea (Liang et al. 2001). However, the species was not confirmed in any subsequent studies.

Species within the genus Perkinsus are typically differentiated using several key phenotypic characters, including host species, pathogen shape and size, and the ultrastructure of the zoospores (Perkins 1969). Similarly, Perkinsus spp. are typically detected by histological examination of sampled tissue and diagnosis by hypnospore culture in fluid thioglycollate medium (FTM). However, ultrastructural observation of the zoospores using transmission electronic microscopy (TEM) has little value for taxonomic distinction, as it is difficult to distinguish Perkinsus sp. from other protists (e.g. Colpodella sp.) based on morphological features alone (Siddall et al. 2001). The development of molecular methods has facilitated the taxonomic identification of Perkinsus sp. Furthermore, the analysis of molecular sequences has permitted the study of the phylogenetic relationship of Perkinsus sp. with other protists. The most common molecular markers for Perkinsus sp. discrimination include the $5.8 \mathrm{~S}$ sequence of the internal transcribed spacer (ITS) region and the nontranscribed spacer (NTS) region of ribosomal DNA (rDNA). Comparison of the ribosomal sequence with reference sequences constitutes the only confirmed method for the identification of Perkinsus sp. (Kotob et al. 1999, Robledo et al. 1999, Casas et al. 2002, Burreson et al. 2005, Park et al. 2005).

In this study, the prevalence and intensity of Perkinsus sp. infection in Ruditapes philippinarum cultured in east China were investigated using the Ray's fluid thioglycollate medium (RFTM) culture assay (Ray 1952) and DNA sequencing to report the phylogenetic relationship of Perkinsus sp. isolates from this study with other Perkinsus spp.

\section{MATERIALS AND METHODS}

Sample collection. Manila clams were collected from 5 bays on the east coast of China: Dandong, Qingdao, Weifang, Ningbo, and Fuzhou (Fig. 1) from May 2008 to May 2009.

Ray's fluid thioglycollate medium (RFTM) culture assay. Samples of the clams were collected randomly by diagonal method for hypnospore culture in the laboratory. The total number of clams selected for diagnosis is shown in Table 1. After the bivalve was opened, part of the gill was excised separately and stored at $-20^{\circ} \mathrm{C}$ for DNA extraction and PCR. The remaining whole tissue of each clam, including the gill, mantle, and muscle, was processed for incubation of hypnospore using the quantitative method described by Ray (1952). In brief, a tissue sample from each clam (1 to $3 \mathrm{~mm}^{3}$ in size) was placed in fluid thioglycollate medium (Fluka) supplemented with $2.5 \%$ chloromycetin (Amresco) and 1\% nystatin (Amresco). After incubation at 22 to $25^{\circ} \mathrm{C}$ in the dark for $7 \mathrm{~d}$, the cellular pellet was harvested by centrifugation at $1500 \times g$ for $5 \mathrm{~min}$ and further digested in $1 \mathrm{ml}$ of $2 \mathrm{M}$ sodium hydroxide for $2 \mathrm{~h}$. The digested cellular material was

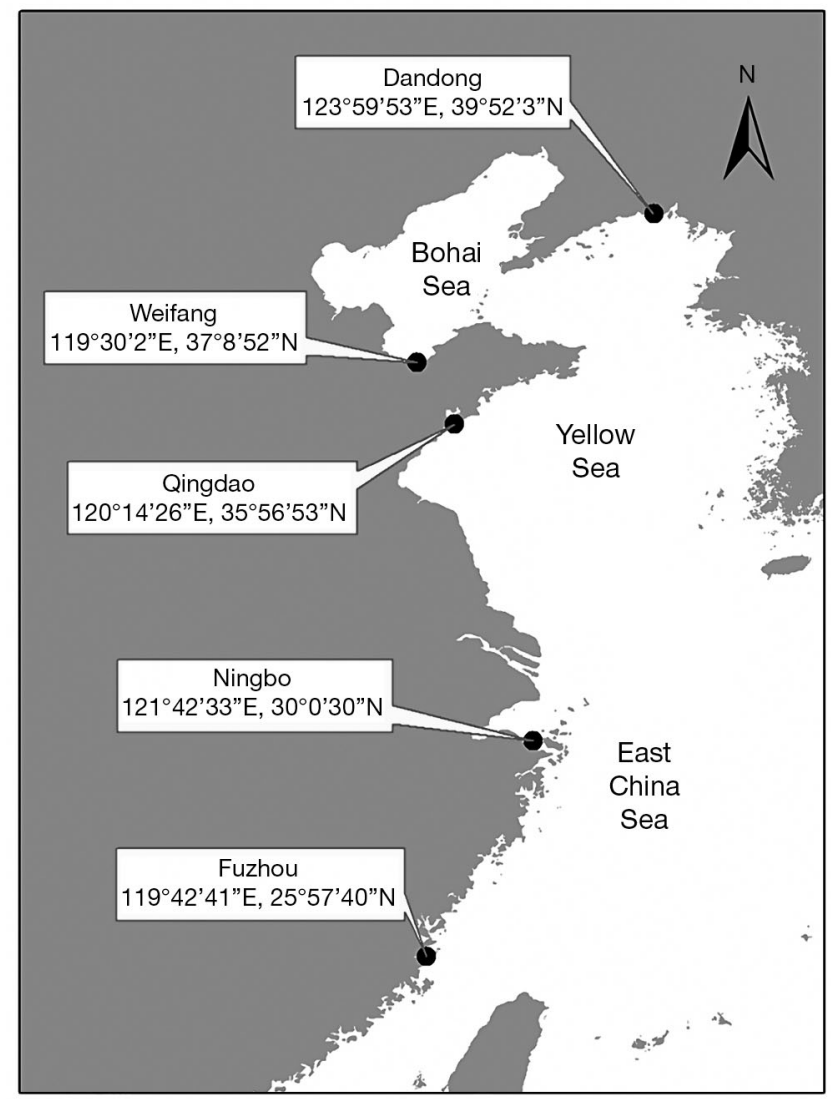

Fig. 1. Ruditapes philippinarum. Collection sites in east China coastal bays 
Table 1. Ruditapes philippinarum. Prevalence of Perkinsus infection in east China coastal bays

\begin{tabular}{|llccc|}
\hline Location & $\begin{array}{c}\text { Sampling } \\
\text { date }\end{array}$ & $\begin{array}{c}\text { No. of clams } \\
\text { examined }\end{array}$ & $\begin{array}{c}\text { No. of positive } \\
\text { samples }\end{array}$ & $\begin{array}{c}\text { Prevalence } \\
(\%)\end{array}$ \\
\hline Yellow Sea, Qingdao & May 2008 & 78 & 36 & 46.00 \\
& Oct 2008 & 120 & 115 & 95.83 \\
& Oct 2008 & 120 & 114 & 95.00 \\
& Oct 2008 & 120 & 106 & 88.33 \\
Yellow Sea, Dandong & Mar 2009 & 80 & 35 & 43.75 \\
Bohai Sea, Weifang & May 2008 & 30 & 0 & 0 \\
& Jul 2008 & 23 & 0 & 0 \\
& Oct 2008 & 23 & 12 & 52.17 \\
& Oct 2008 & 23 & 7 & 30.43 \\
East China Sea, & May 2009 & 120 & 0 & 0 \\
Fuzhou & Nov 2008 & 40 & 36 & 90.00 \\
East China Sea, & Nov 2008 & 27 & 25 & 92.59 \\
Ningbo & May 2009 & 23 & 13 & 56.52 \\
& & & & \\
\hline
\end{tabular}

then centrifuged and the pellet was rinsed 3 times with $0.1 \mathrm{M}$ phosphate-buffered solution (PBS) containing $0.1 \%$ bovine serum albumin (BSA). The pellet was suspended in $2 \mathrm{ml}$ of deionized water and the suspension was mounted on a glass slide, stained with Lugol's iodine solution according to Choi et al. (1989), and then examined under a microscope for the presence of hypnospores.

DNA extraction. Genomic DNA was extracted from the excised gill tissue using a DNeasy Tissue Kit (Qiagen), following the manufacturer's protocol with some modifications. The gill mixture of 5 clams collected during one round of diagonal sampling procedure was frozen in liquid nitrogen for $5 \mathrm{~min}$ then ground into powder. The powder was then digested with proteinase $\mathrm{K}\left(600 \mathrm{mAU} \mathrm{ml}{ }^{-1}\right.$, Merck) at $55^{\circ} \mathrm{C}$ overnight. Following extraction, the final genomic DNA was eluted with $50 \mu \mathrm{l}$ deionized water and stored at $-20^{\circ} \mathrm{C}$ until use. Three genomic DNA extracts were collected for each batch of sample.

PCR, cloning, and sequence analysis. The Perkinsus-specific ITS-1 to ITS-2 ribosomal DNA primers PerkITS85 and PerkITS750 (Casas et al. 2002), which were expected to amplify a 673 base pair (bp) DNA fragment, were chosen to amplify the Perkinsus-specific ITS-1 to ITS-2 ribosomal DNA fragment. For the negative control, the template DNA was substituted with deionized, nuclease-free water. The PCR reaction solution consisted of $20 \mathrm{mM}$ Tris- $\mathrm{HCl}$ ( $\mathrm{pH}$ 8.0), $50 \mathrm{mM}$ $\mathrm{KCl}, 1.5 \mathrm{mM} \mathrm{MgCl}_{2}, 0.2 \mathrm{mM}$ of each dNTP, $0.2 \mu \mathrm{M}$ of each primer, $2.5 \mathrm{U}$ rTaq polymerase (TaKaRa), and $5 \mu \mathrm{l}$ of the purified genomic DNA. The thermal program consisted of an initial denaturation at $94^{\circ} \mathrm{C}$ for $5 \mathrm{~min}$ followed by 35 cycles of $94^{\circ} \mathrm{C}$ for $1 \mathrm{~min}, 55^{\circ} \mathrm{C}$ for $1 \mathrm{~min}$, and $72^{\circ} \mathrm{C}$ for $2 \mathrm{~min}$, and a final elongation step at $72^{\circ} \mathrm{C}$ for $5 \mathrm{~min}$. The PCR product $(5 \mu \mathrm{l})$ was examined by electrophoresis in a $1 \%$ agarose gel, stained with $\mathrm{SyBr}$ Green (Invitrogen), and visualized under UV light.

The amplified DNA product with the expected size was excised from the gel and purified using the Gel Extraction Kit (Omega Bio-Tek). After quantification, the amplicon was ligated to the pGEM-T easy vector (Promega) and transformed to E. coli JM109 competent cells (TaKaRa). Positively transformed bacterial colonies were initially screened using the blue and white colony selection method, followed by screening for inserts using the PCR protocol described above. The PCR product was sequenced using the $\mathrm{T} 7$ and SP6 sequencing primer pairs on an ABI 377 DNA Sequencer. The three DNA sequences amplified each time were compared and the universal sequence was analyzed using the basic local alignment search tool (BLAST) online (http://blast.ncbi.nlm. nih.gov/Blast.cgi) and aligned to available sequences for Perkinsus spp. deposit in the GenBank database using the CLUSTAL-W algorithm (Thompson et al. 1994). To determine the taxonomic affiliation of the Perkinsus isolates with other congeneric species, phylogenetic analyses of all the isolates were performed using maximum-parsimony (MP) methods in MEGA version 4 (Tamura et al. 2007) with 1000 replicates for bootstrap values.

\section{RESULTS}

\section{Prevalence of perkinsosis in clams}

Hypnospores were identified in 10 out of the 13 batches and from all 5 sites. The rate of infection ranged from 43.75 to $95.83 \%$ (Table 1 ). The only 3 uninfected batches were all collected at Weifang Bay in the Bohai Sea, the site farthest from the ocean. The hypnospores were spherical with diameter 30 to $80 \mu \mathrm{m}$, and the cell wall was stained bluish-black with Lugol's iodine solution revealing the vesicles internally (Fig. 2).

\section{Amplification of Perkinsus ITS DNA and phylogenetic analysis}

Electrophoresis of the PCR product revealed an approximate $673 \mathrm{bp}$ amplicon. The sequences of the isolates were subjected to phylogenetic analysis 


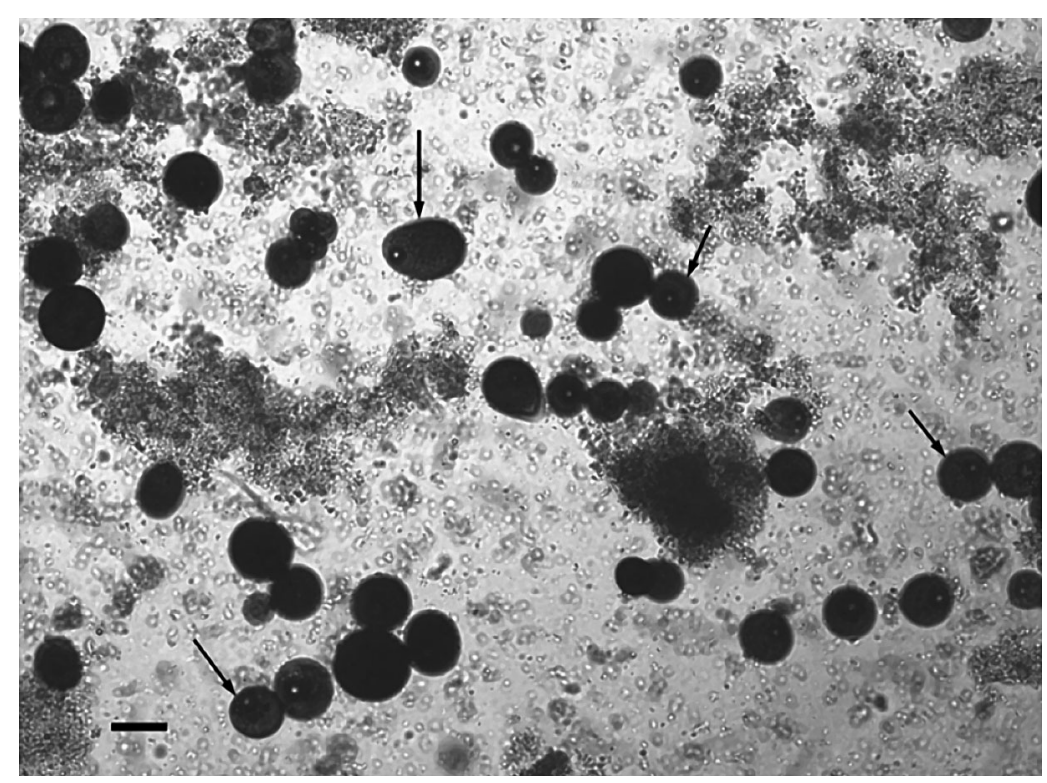

Fig. 2. Perkinsus sp. after FTM culture and staining with Lugol's solution (200×). Hypnospores are indicated by arrows. Scale bar $=50 \mu \mathrm{m}$

perkinsosis was absent from Arguin (Arcachon Bay, France), an area characterized by relatively constant salinity

The prevalence of Perkinsus olseni was significantly greater in October than in May suggesting that prevalence varies seasonally. This is consistent with Park et al. (2006) who reported relatively low infection intensity during summer in Korean waters. Similarly, Uddin et al. (2010) reported lower infection intensity and prevalence levels from March to August and higher levels from September to January for $P$. olseni in Manila clams. Villalba et al. (2005) reported on the seasonality of $P$. olseni infection intensity and prevalence in the carpet shell clam Ruditapes decussatus in Galicia, Spain. Over 5 yr of monitoring, the infection intensity and prevalence were lower in winter and higher from spring to autumn, with 2 main annual peaks in spring and late summer/early

against Perkinsus sequences of the known species deposited in GenBank by maximum parsimony method using the software MEGA 4.0. All the sequences of the isolates were grouped in the same clade as other known $P$. olseni sequences isolated from Japan (DQ516712), Korea (AF473840), and Australia (U07697) and $P$. atlanticus sequences isolated from Japan (AF509333). Conversely, the isolate sequences were distinct from several other Perkinsus species, including P. marinus (AF126022, AF295179), P. chesapeaki (DQ370493, AY876304), P. mediterraneus (AY487834, EU068097), P. honshuensis, and P. qugwadi (AF151528) (Fig. 3).

\section{DISCUSSION}

Perkinsus olseni infections were widespread in Manila clams along the east coast of China. The only uninfected clams were collected at Weifang Bay of the Bohai Sea. The low infection intensity and prevalence of $P$. olseni at this site is likely related to the relative lack of tidal and oceanic influences when compared with the other sites. The salinity is relatively constant in Weifang Bay, ranging from 28 to 38 ppt throughout the year (Wang et al. 2010). A number of studies have shown that the abundance and prevalence of Perkinsus sp. is strongly influenced by salinity. For example, Park \& Choi (2001) demonstrated that perkinsosis was absent at sites where salinity remained constant throughout the year. Similarly, Dang et al. (2010) noted that autumn. The temporal variation in infection intensity and prevalence is closely linked with seasonal changes in seawater temperature. The high prevalence and intensity of infection observed at high temperatures and salinity during the summer is likely associated with increases in parasite multiplication rates and decreases in host defense capabilities and physiological condition (Burreson \& Calvo 1996).

The significantly higher infection prevalence during fall (September to November) compared with other seasons may be related to the post-spawning condition of the clams. As the clams exhaust themselves during spawning, they may become more susceptible to Perkinsus olseni infection. Park et al. (2006) also observed higher levels of $P$. olseni infection during the post-spawning period in Ruditapes philippinarum in Gomso Bay on the west coast of Korea. Immune parameters such as the number and viability of hemocytes also decrease after spawning in Manila clams, which may increase their susceptibility to $P$. olseni infection (Soudant et al. 2004).

The sequence data from the Perkinsus isolates were within the range of intraspecific variance observed for $P$. olseni. Thus, the isolates were classified as $P$. olseni. The phylogenetic groupings derived from these results were similar to those of Park et al. (2005) who showed a high degree of sequence divergence between Korean Perkinsus isolates and other congeneric species, including $P$. marinus and $P$. andrewsi, but only minor sequence differentiation between Korean Perkinsus and Japanese Perkinsus. 
GU233528(Ruditapes philippinarum-China) GU233522(Ruditapes philippinarum-China) GU233523(Ruditapes philippinarum-China) GU233529(Ruditapes philippinarum-China) GU233531(Ruditapes philippinarum-China) GU233530(Ruditapes philippinarum-China) GU233525(Ruditapes philippinarum-China) DQ516715(Ruditapes philippinarum-Japan) DQ194978(Ruditapes decussatus-Spain) GU233527(Ruditapes philippinarum-China) GU377507(Ruditapes philippinarum-China) GU377512(Ruditapes philippinarum-China) GU377508(Ruditapes philippinarum-China) GU233524(Ruditapes philippinarum-China) DQ516712(Ruditapes philippinarum-Japan) GU377509(Ruditapes philippinarum-China) GU377510(Ruditapes philippinarum-China) GU233532(Ruditapes philippinarum-China) GU233521(Ruditapes philippinarum-China) GU233526(Ruditapes philippinarum-China) AF509333(Ruditapes decussatus-Portugal) U07697 (Ruditapes decussatus-Australia) GU377511(Ruditapes philippinarum-China) GU377513(Ruditapes philippinarum-China) FJ841985(Ruditapes philippinarum-China) EU871715(Tridacna crocea-Viet Nam)

85 DQ516696(Ruditapes philippinarum-Japan) 78 AY487834(Ostrea edulis-Spain) 77 L EU068097(Ostrea edulis-Spain) AF126022(Crassostrea virginica-USA) 97 AY295179(Crassostrea virginica-USA) 100 AY876304(Ruditapes philippinarum-Japan)

L DQ370493(Ostrea edulis-Spain) EU068101(Crassostrea hongkongensis-China) 99 EU068107(Crassostrea hongkongensis-China) AF151528(Patinopecten yessoensis-Canada)

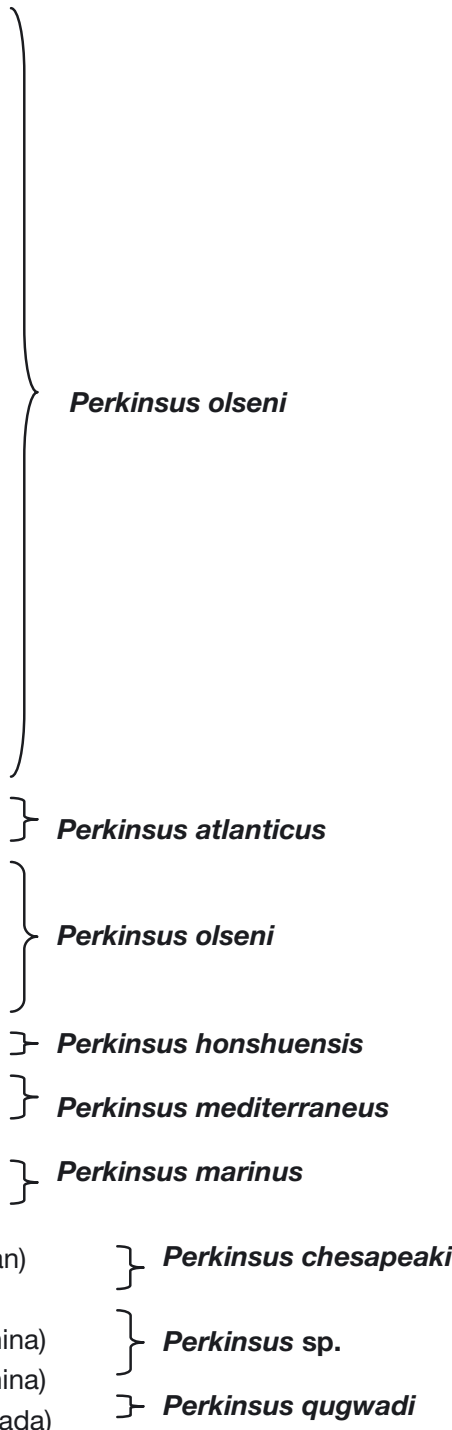

0.05

Fig. 3. Perkinsus spp. Phylogenetic analysis of isolates based on the ITS region sequences. (Nucleotide sequence data reported in this paper are available in the GenBank database under the accession numbers FJ841985, GU377507-13)

Acknowledgements. The project was supported by the National Natural Science Foundation of China (30973180) and the scientific project of AQSIQ (2007IK038, 201010016).

\section{LITERATURE CITED}

Burreson EM, Calvo LMR (1996) Epizootiology of Perkinsus marinus disease of oysters in Chesapeake Bay, with emphasis on data since 1985. J Shellfish Res 15:17-34

Burreson EM, Reece KS, Dungan CF (2005) Molecular, morphological, and experimental evidence support the synonymy of Perkinsus chesapeaki and Perkinsus andrewsi. $\mathrm{J}$ Eukaryot Microbiol 52:258-270

Casas SM, Villalba A, Reece KS (2002) Study of perkinsosis in the carpet shell clam Tapes decussatus in Galicia (NW Spain). I. Identification of the aetiological agent and in vitro modulation of zoosporulation by temperature and salinity. Dis Aquat Org 50:51-65

Choi KS, Park KI (1997) Report on the occurrence of Perkinsus sp. in the Manila clam, Ruditapes philippinarum, in Korea. Aquaculture 10:227-237

Choi KS, Wilson EA, Lewis DH, Powell EN, Ray SM (1989) The energetic cost of Perkinsus marinus parasitism in oysters: quantification of the thioglycollate method. J Shellfish Res 8:125-131

> Dang C, Montaudouin X, Caill-Milly N, Trumbiç Î (2010) Spatio-temporal patterns of perkinsosis in the Manila clam Ruditapes philippinarum from Arcachon Bay (SW France). Dis Aquat Org 91:151-159 
Dungan CF, Reece KS (2006) In vitro propagation of two Perkinsus spp. parasites from Japanese manila clams Venerupis philippinarum and description of Perkinsus honshuensis n. sp. J Eukaryot Microbiol 53:316-326

Dungan CF, Reece KS, Moss JA, Hamilton RM, Diggles BK (2007) Perkinsus olseni in vitro isolates from the New Zealand clam Austrovenus stutchburyi. J Eukaryot Microbiol 54:263-270

Elandaloussi L, Carrasco N, Furones D, Roque A (2009) Phylogenetic relationship of Perkinsus olseni from the Ebro Delta, Spain, to other Perkinsus species, based on ribosomal DNA sequences. Dis Aquat Org 86:135-142

Fernández-Robledo JA, Lin Z, Vasta GR (2008) Transfection of the protozoan parasite Perkinsus marinus. Mol Biochem Parasitol 157:44-53

Hamaguchi M, Suzuki N, Usuki H, Ishioka H (1998) Perkinsus protozoan infection in short-necked clam Tapes (=Ruditapes) philippinarum in Japan. Fish Pathol 33:473-480

Kotob SI, McLaughlin SM, Van Berkum P, Faisal M (1999) Discrimination between two Perkinsus spp. isolated from the softshell clam, Mya arenaria, by sequence analysis of two internal transcribed spacer regions and the 5.8S ribosomal RNA gene. Parasitology 119:363-368

Leethochavalit S, Chalermwat K, Upatham ES, Choi KS, Sawangwong $\mathrm{P}$, Kruatrachue M (2004) Occurrence of Perkinsus sp. in undulated surf clams, Paphia undulata, from the Gulf of Thailand. Dis Aquat Org 60:165-171

Lester RJG, Davis GHG (1981) A new Perkinsus species (Apicomplex, Perkinsea) from the abalone Haliotis ruber. J Invertebr Pathol 37:181-187

Liang YB, Zhang XC, Wang LJ, Yang B, Zhang Y, Cai CL (2001) Prevalence of Perkinsus sp. in the Manila clam, Ruditapes philippinarum, along the northern coast of the Yellow Sea in China. Oceanol Limnol Sin 32:502-511

Murrell A, Kleeman SN, Barker SC, Lester RJG (2002) Synonymy of Perkinsus olseni (Lester \& Davis 1981) and Perkinsus atlanticus (Azevedo 1989), and an update on the phylogenetic position of the genus Perkinsus. Bull Eur Assoc Fish Pathol 22:258-265

Ordas MC, Gomez-leon J, Figueras A (2001) Histopathology of the infection by Perkinsus atlanticus in three clam species (Ruditapes decussates, R. philippinarum and R. pullastra) from Galicia (NW Spain). J Shellfish Res 20:1019-1024

Park KI, Choi KS (2001) Spatial distribution and infection intensity of the protozoan parasite Perkinsus sp. in the Manila clam Ruditapes philippinarum in Korea. Aquaculture 203:9-22

Park KI, Park JK, Lee J, Choi KS (2005) Use of molecular markers for species identification of Korean Perkinsus sp. isolated from Manila clams Ruditapes philippinarum. Dis Aquat Org 66:255-263

Park KI, Ngo TT, Choi SD, Cho M, Choi KS (2006) Occurrence

Editorial responsibility: Mike Hine,

Fouras, France of Perkinsus olseni in the Venus clam Protothaca jedoensis in Korean waters. J Invertebr Pathol 93:81-87

Perkins FO (1969) Ultrastructure of vegetative stages in Labyrinthomyxa marina (=Dermocystidium marinum), a commercially significant oyster pathogen. J Invertebr Pathol 13:199-222

Ray SM (1952) A culture technique for the diagnosis of infection with Dermocystidium marinum Mackin, Owen, and Collier in oysters. Science 116:360-361

Robledo JA, Wright AC, Marsh AG, Vasta GR (1999) Nucleotide sequence variability in the nontranscribed spacer of the rRNA locus in the oyster parasite Perkinsus marinus. J Parasitol 85:650-656

Sheppard BJ, Phillips AC (2008) Perkinsus olseni detected in Vietnamese aquacultured reef clams Tridacna crocea imported to the USA, following a mortality event. Dis Aquat Org 79:229-235

> Shimokawa J, Yoshinaga T, Ogawa K (2010) Experimental evaluation of the pathogenicity of Perkinsus olseni in juvenile Manila clams Ruditapes philippinarum. J Invertebr Pathol 105:347-351

Siddall ME, Reece KS, Nerad TA, Burreson EM (2001) Molecular determination of the phylogenetic position of a species in the genus Colpodella (Alveolata). Am Mus Novit 3314:1-10

Soudant P, Paillard C, Choquet G, Lambert C and others (2004) Impact of season and rearing site on the physiological and immunological parameters of the Manila clam Venerupis (=Tapes, =Ruditapes) philippinarum. Aquaculture 229:401-418

Tamura K, Dudley J, Nei M, Kumar S (2007) MEGA4: Molecular Evolutionary Genetics Analysis (MEGA) software version 4.0. Mol Biol Evol 24:1596-1599

> Thompson JD, Higgins DG, Gibson TJ (1994) CLUSTAL W: Improving the sensitivity of progressive multiple sequence alignment through sequence weighting, positions-specific gap penalties and weight matrix choice. Nucleic Acids Res 22:4673-4680

Uddin JM, Yang HS, Choi KS, Kim HJ, Hong JS, Cho M (2010) Seasonal changes in Perkinsus olseni infection and gametogenesis in Manila clam, Ruditapes philippinarum, from Seonjaedo Island in Incheon, off the west coast of Korea. J World Aquacult Soc 41:93-101

Villalba A, Casas SM, Lopez C, Carballal MJ (2005) Study of perkinsosis in the carpet shell clam Tapes decussatus in Galicia (NW Spain). II. Temporal pattern of disease dynamics and association with clam mortality. Dis Aquat Org 65:257-267

Wang GN, Jiang LX, Wang SH, Yang N, Li ZX, Wu WJ, Wang WQ (2010) Influence of salinity on the ingestion rate and clearance rate of Ruditapes philippinarum. Mark Sci 34: $6-8$

Submitted: January 27, 2011; Accepted: March 2, 2011

Proofs received from author(s): July 8, 2011 